ISSN 0258-7122

Bangladesh J. Agril. Res. 40(1): 1-16, March 2015

\title{
THE THIRD GENOTYPIC CLUSTERS OF Bemisia tabaci (GENNADIUS) (HEMIPTERA: ALEYRODIDAE) FOUND IN BANGLADESH
}

\author{
JAHAN, S. M. H. ${ }^{1}$, LEE, K-Y. ${ }^{2}$ AND HOWLADER, M. I. A. ${ }^{3}$
}

\begin{abstract}
The sweetpotato whitefly, Bemisia tabaci is a species complex that possessed several biotypes including different genotypic clusters within species, which may differ from each other genetically and physiologically but morphologically alike. This study was performed by molecular analysis for easy identification of whitefly and describes its biotype throughout Bangladesh. Whiteflies have been identified from different places of Bangladesh based on mitochondrial cytochrome oxidase subunit I (mtCOI) gene and 16S ribosomal RNA gene sequences analysis. The mtCOI sequences of BW3 (collected from eastern part of Bangladesh) whitefly were diverged by $14.5 \%$ and $15.1 \%$ compared with B and Q biotypes from Korea and it also diverged by $15.4 \%$ and $13.7 \%$ from each other compared to BW1 (collected from southern part of Bangladesh) and BW2 (collected from northern part of Bangladesh), respectively within the country. The 16S rRNA sequences of BW3 whitefly were more deviated by $41.5 \%$, $10.7 \%, 42.7 \%$ and $12.6 \%$ compared with the country populations from BW1, BW2, B and Q biotypes, respectively. Moreover, it showed high divergences from indigenous whiteflies of southern and northern part of Bangladesh which clustered in a different clade on both mtCOI and 16S rRNA phylogeny. Therefore, till date three genotypic cluster of indigenous whitefly BW1, BW2 and BW3 are identified from Bangladesh.
\end{abstract}

Keywords: Bemisia tabaci, BW3, mtCOI gene, 16S rRNA gene, indigenous whitefly.

\section{Introduction}

The whitefly, Bemisia tabaci (Gennadius) (Hemiptera: Aleyrodidae) is a very complex species consists of at least 24 biotypes in tropical and sub-tropical region around the World (Ahmed et al., 2009). This devastating global insect pest caused damage directly by sucking the plant sap from phloem, indirectly by excreting honeydews that produce sooty mould, and by spreading 111 plant virus diseases (Martin et al., 2000; Jones, 2003; Mughra et al., 2008). Bemisia tabaci is a genetically different groups of insect that morphologically indistinguishable (Frohlich et al., 1999; De Barro et al., 2000; Boykin et al., 2007). Significant

${ }^{1}$ Professor, Department of Entomology, Patuakhali Science and Technology University, Dumki, Patuakhali-8602, ${ }^{2}$ Professor, Department of Agricultural Biology, Kyungpook National University, Daegu 702-701, Korea, ${ }^{3}$ Senior Scientific Officer, On-Farm Research Division, Bangladesh Agricultural Research Institute, Patuakhali-8600, Bangladesh. 
attempt has been committed to the analysis of the biological and genetic variation of B. tabaci and has been recognized different biotypes into the species (Perring, 2001). Among them, two predominantly aggressive biotypes, known as B and Q, are distributed everywhere around the World (De Barro, 2005; De Barro et al., 2005; Chu et al., 2006; Martinez-Carrillo \& Brown, 2007) whereas, in Bangladesh yet B and/ or Q biotype are absent but indigenous biotype BW1 and BW2 recorded recently (Maruthi et al., 2007; Jahan et al., 2011; Jahan, 2012). The B. tabaci is not genetically consistent. Based on mitochondrial DNA markers, the $B$. tabaci complex can be placed into five major groups according to their geographical origin: (1) New World (US, Mexico, Puerto Rico), (2) Southeast Asia (Thailand, Malaysia), (3) Mediterranean basin (Southwest Europe, North Africa, Middle East), (4) Indian subcontinent (Bangladesh, India, Myanmar, Nepal and Pakistan), (5) Equatorial Africa (Cameroon, Mozambique, Uganda, and Zambia); an additional more distantly related group contained the B relatives from many world sites and the non-B relatives from the Middle East (Frohlich et al., 1999). At least three distinct genotypes, apparently indigenous to India, which are also present in China, Malaysia, Nepal, Pakistan and Thailand. These coexist with the B biotype, which was first reported in India in 1999, and has since spread rapidly to other states in south India (Rekha et al., 2005). This may support the conclusion of De Barro et al. (2005) that using mtCOI and internal transcribed spacer region 1 (ITS1) markers, some individuals from Asia did not fit into either of the two clusters (called Asia1 and Asia2), and they remained classified as 'unresolved' in the Asia group. In a similar study, two indigenous $B$. tabaci genotypes have been reported from neighboring Pakistan, and one from the Punjab area was similar to the Indian populations (Brown, 2001; Simon et al., 2003), suggesting their wider occurrence. The mtCOI DNA diversity of Asian B. tabaci therefore is comparable to that from African populations, where at least five distinct clades of $B$. tabaci have been recorded on cassava (Legg et al., 2002; Berry et al., 2004).

In this study, the genetic differences between the B. tabaci B and Q biotype populations from Korea and indigenous whitefly from Bangladesh which was collected from various places on different host-plants as bean, eggplant, and okra were investigated for identification.

\section{Materials and Method}

\section{Whiteflies collection}

Samples of adult B. tabaci were collected from bean, eggplant and okra of different places of eastern part of Bangladesh such as, Chittagong and Cox's Bazar in 2012 (Table 1) and were immediately preserved in 99\% ethanol (alcohol) and stored at $-20^{\circ} \mathrm{C}$. Adults of $\mathrm{B}$. tabaci $\mathrm{B}$ and $\mathrm{Q}$ biotypes were collected from whitefly rearing house in Insect Molecular Physiology Laboratory 
at Kyungpook National University in South Korea on cucumber and tomato plants in 2011 for morphological and genetic sequences comparison of Bangladesh whiteflies.

\section{DNA extraction}

Total genomic DNA was extracted from individual B. tabaci according to protocol supplied by Invitrogen Purelink Genomic DNA mini kit. After removing from ethanol the sample had been washed with double-distilled water to remove alcohol, individual whiteflies were homogenized in $180 \mu \mathrm{l}$ genomic digestion buffer using a $1.5 \mathrm{ml}$ microcentrifuge tube and micropestle (homogenizer). Then added $200 \mu$ l genomic lysis/ binding buffer (1\% SDS, $10 \mathrm{mM}$ Tris-HCl, $\mathrm{pH}$ 8.0, $25 \mathrm{mM}$ EDTA, $25 \mathrm{mM} \mathrm{NaCl}$, Proteinase K $200 \mathrm{mg} / \mathrm{ml}$ ) and after that immediately added $200 \mu \mathrm{l}$ absolute ethanol. Subsequently added wash buffer into the genomic column and finally added $20 \mu \mathrm{l}$ genomic elusion buffer (Invitrogen Purelink, Carisbad, CA, USA). After $1 \mathrm{~min}$ incubation at room temperature, samples were centrifuged at about $12000 \mathrm{rpm}$ for $1 \mathrm{~min}$, and the supernatants/pellets were directly used for PCR detection of the secondary endosymbionts or were stored at $-20^{\circ} \mathrm{C}$ for later use. These procedures were followed by Dellaporta et al., 1983 and Jahan et al., 2011.

Table 1. List of collection with GenBank accession no. for the sequences of collected B. tabaci in Bangladesh.

\begin{tabular}{ccccccc}
\hline $\begin{array}{c}\text { Name of } \\
\text { Specimen }\end{array}$ & Host plant & Location & Year & Gene & $\begin{array}{c}\text { GenBank } \\
\text { Accession no. }\end{array}$ \\
\hline B. tabaci & Bean & Chittagong & 2012 & mtCOI & JX417071 \\
B. tabaci & Bean & Chittagong & 2012 & 16S rRNA & JX417075 \\
B. tabaci & Bean & Patuakhali & 2011 & mtCOI & JN018067 \\
B. tabaci & Bean & Patuakhali & 2011 & 16S rRNA & JQ305697 \\
B. tabaci & Eggplant & Chittagong & 2012 & mtCOI & JX417072 \\
B. tabaci & Eggplant & Chittagong & 2012 & 16S rRNA & JX417076 \\
B. tabaci & Eggplant & Kurigram & 2011 & mtCOI & JQ305088 \\
B. tabaci & Eggplant & Kurigram & 2011 & 16S rRNA & JQ305699 \\
B. tabaci & Eggplant & Cox's Bazar & 2012 & mtCOI & JX417073 \\
B. tabaci & Eggplant & Cox's Bazar & 2012 & 16S rRNA & JX417077 \\
B. tabaci & Okra & Cox's Bazar & 2012 & mtCOI & JX417074 \\
B. tabaci & Okra & Cox's Bazar & 2012 & 16S rRNA & JX417078 \\
\hline
\end{tabular}

\section{Primer design and PCR amplification}

Bemisia tabaci was determined using the genomic DNA which was collected from Bangladesh with the primers listed in Table 2, using Polymerase Chain 
Reaction (PCR). All PCR reaction mixture performed in $20 \mu \mathrm{l}$ volume that included $1 \mu \mathrm{l}$ of each primer (Forward and Reverse), $1 \mu \mathrm{l}$ of DNA template and $17 \mu \mathrm{l}$ smart buffer which were supplied by the manufacturer (Smart taq pre-mix). All PCR reactions were carried out on the PTC-200 DNA engine thermal cycler (MJ Research PTC-200 DNA Engine Thermal Cycler PCR).

Table 2. Nucleotide sequences of primers listed for B. tabaci identification.

\begin{tabular}{|c|c|c|c|c|c|c|}
\hline Gene & $\begin{array}{l}\text { Primer } \\
\text { Name }\end{array}$ & $\begin{array}{c}\text { Primer } \\
\text { Direction }\end{array}$ & $\begin{array}{l}\text { Primer Sequence } \\
\quad\left(5^{\prime} \text { to } 3^{\prime}\right)\end{array}$ & $\begin{array}{l}\text { Size } \\
\text { (bp) }\end{array}$ & Reference & $\begin{array}{l}\mathrm{Tm} . \\
\left({ }^{\circ} \mathrm{C}\right)\end{array}$ \\
\hline $\mathrm{mtCOI}$ & $\begin{array}{c}\text { C1-J-2195 } \\
\text { L2-N- } \\
3014\end{array}$ & $\begin{array}{l}\text { Forward } \\
\text { Reverse }\end{array}$ & $\begin{array}{c}\text { TTGATTTTTTGGTCAT } \\
\text { CCAGAAGT } \\
\text { TCCAATGCACTAATC } \\
\text { TGCCATATTA }\end{array}$ & 860 & $\begin{array}{l}\text { Simon et } \\
\text { al. } 1994\end{array}$ & $52^{\circ} \mathrm{C}$ \\
\hline $\begin{array}{l}16 \mathrm{~S} \\
\text { rRNA }\end{array}$ & $\begin{array}{l}\text { LR-J- } \\
12887 \\
\text { LR-N- } \\
13398\end{array}$ & $\begin{array}{l}\text { Forward } \\
\text { Reverse }\end{array}$ & $\begin{array}{c}\text { CCGGTTTGAACTCAG } \\
\text { ATCATGT } \\
\text { CGCCTGTTTAACAAA } \\
\text { AACAT }\end{array}$ & 520 & $\begin{array}{l}\text { Simon et } \\
\text { al. } 1994\end{array}$ & $55^{\circ} \mathrm{C}$ \\
\hline
\end{tabular}

\section{PCR condition}

The mixtures with the cytochrome oxidase sub-unit1 (CO1) primer C1-J-2195(F) and L2-N-3014(R) were amplified in a PTC-200 thermal cycler (MJ Research, Watertown, MA, USA) with a 1 minute initial denaturation at $95^{\circ} \mathrm{C}, 35$ cycles (1 min at $94^{\circ} \mathrm{C}, 30 \mathrm{sec}$ at $52^{\circ} \mathrm{C}, 2 \mathrm{~min}$ at $72^{\circ} \mathrm{C}$ ), and finally by a 5 min extension at $72^{\circ} \mathrm{C}$. For $16 \mathrm{~S}$ rRNA primers LR-J-12887 (F) and LR-N-13398 (R) were also amplified with a 2 min initial denaturation at $94^{\circ} \mathrm{C}, 35$ cycles $\left(30 \mathrm{sec}\right.$ at $94^{\circ} \mathrm{C}, 1$ min at $55^{\circ} \mathrm{C}, 1 \mathrm{~min}$ at $72^{\circ} \mathrm{C}$ ), and finally by a $10 \mathrm{~min}$ extension at $72^{\circ} \mathrm{C}$.

\section{Gel-electrophoresis}

Electrophoresis of amplified PCR products $(5 \mu \mathrm{l})$ were done using $1.0 \%$ agarose gels with $1 \%$ TAE buffer at $100 \mathrm{~V}$ for 30 minutes with $100 \mathrm{bp}$ ladder as DNA marker and the gels were then stained by $10 \mu \mathrm{l}$ Ethidium Bromide for 20 minutes. When fragments with the expected size were visible on the gels, then the rest of $15 \mu \mathrm{l}$ of PCR products were used for sequencing.

\section{Sequence analysis}

DNA sequences were aligned using CLUSTAL W (Thompson et al., 1994). The aligned sequences were checked and compared the sequences similarity with the online published sequences using BLAST in the National Centre for Biotechnology Information (NCBI). Sequences were aligned and arranged using 
the Clustal W2 multiple alignments in BioEdit (version 7.0). The sequences divergences calculated by Molecular Evolutionary Genetics Aanlysis (MEGA) among intraspecific, interspecific species, based on Kimura-2-parameter (K2P) distances (Tamura et al., 2007). Phylogenetic relationships were inferred by MEGA Software Version 4.0 (Tamura et al., 2007) using neibour-joining method (NJ). Bootstrap values were obtained from 1000 replicates. The sequences are deposited in the GenBank database.

\section{Results}

\section{Identification of B. tabaci in Bangladesh}

The sweetpotato whitefly, B. tabaci was identified from the collected specimen in Bangladesh using PCR, and compared the similarity of mtCOI and 16S rRNA gene sequences with related information published in NCBI database. The DNA fragment at 860 bp to C1-J-2195(F) and L2-N-3014(R) and at 520 bp to LR-J12887 (F) and LR-N-13398 (R) primer sets were shown in PCR amplification (Figure 1). The partial mtCOI and 16S rRNA gene sequences have been provided here that was submitted for registration to the NCBI GenBank database (Table1). Moreover, we provide here the comparison of similarity using both mtCOI and 16S rRNA nucleotides in total length of sequences (Table 3 ). We found that all sequences showed maximum similarity with $B$. tabaci around the World.

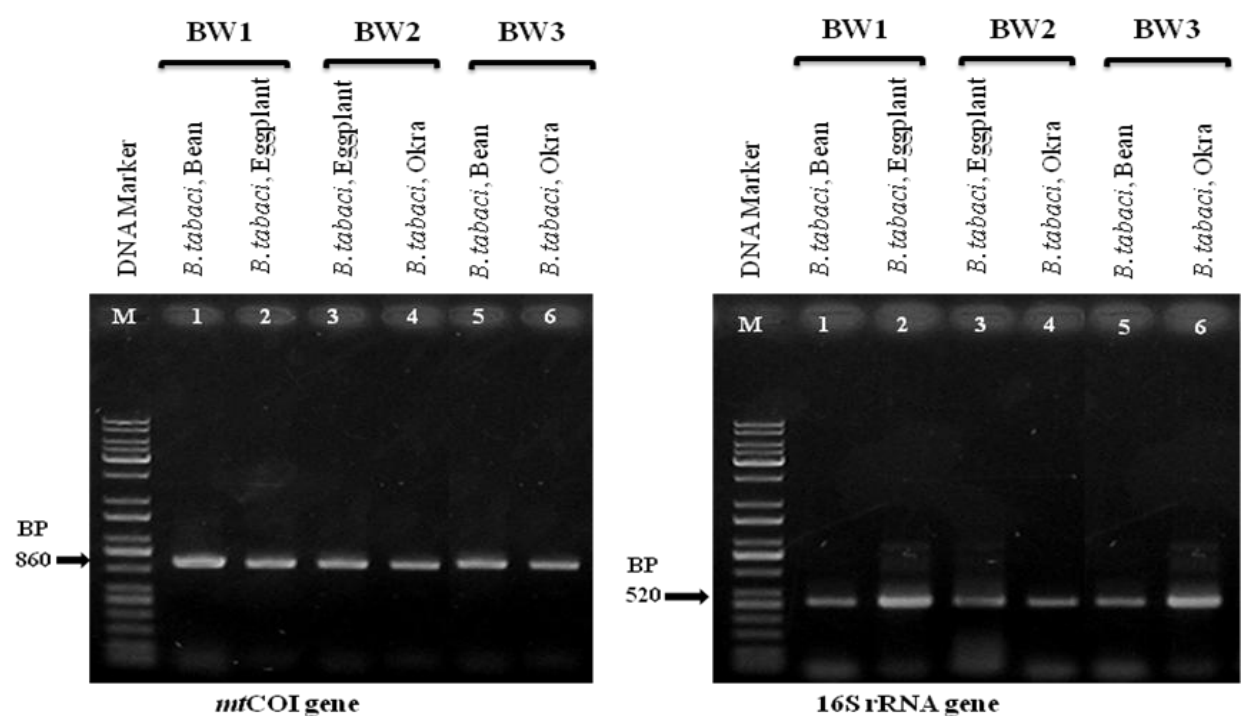

Figure1. PCR Amplification of mtCOI gene region of $B$. tabaci with C1-J-2195 and L2-N-3014 primers and 16S rRNA gene with LR-J-12887 and LR-N13398 primer set to distinguish $B$. tabaci. M: molecular weight standardDNA marker (100 bp ladder). 


\section{Biotype detection from Bangladesh whiteflies}

Biotype of B. tabaci collected from Bangladesh has been examined using PCR amplification with 16S rRNA gene sequence digested with restricted enzyme Hinf1 (Figure 1). The result revealed that collected whiteflies from eastern part of Bangladesh are indigenous (native) BW3 biotype (Figure $4 \& 5$ ). More interesting things that collected samples from eastern part were shown very dissimilarity from B biotype, Q biotype and previously collected BW1 BW2 whitefly but they all are truly indigenous whitefly (Figure $4 \& 5$ ). We revealed another new genotypic cluster of B. tabaci (BW3) in Bangladesh. This new genotype of whiteflies showed score of similarity $85.51 \%, 84.87 \%, 84.61 \%$ and $86.32 \%$ with B and Q biotype (Korea), BW1 (southern part of Bangladesh) and BW2 (northern part of Bangladesh), respectively for mtCOI gene (Table 3). The 16S rRNA sequences of BW3 (newly collected from eastern part of Bangladesh) whitefly were shown similarity by $57.32 \%, 87.38 \%, 58.54 \%$ and $89.29 \%$ compared with B biotype, Q biotype, BW1 and BW2, respectively (Table 3).

Table 3. Similarity of both mtCOI and 16S rRNA nucleotide sequences of B. tabaci from each other with another biotype.

\begin{tabular}{ll|c|c}
\hline \multicolumn{1}{c|}{$\begin{array}{c}\text { Sequence of } \\
\text { B. tabaci (A) }\end{array}$} & \multicolumn{1}{c|}{$\begin{array}{c}\text { Sequence of } \\
\text { B. tabaci (B) }\end{array}$} & $\begin{array}{c}\text { Score of } \\
\text { Similarity of } \\
\text { mtCOI (\%) }\end{array}$ & $\begin{array}{c}\text { Score of } \\
\text { Similarity of } \\
\text { 16S rRNA } \\
(\%)\end{array}$ \\
\hline $\begin{array}{l}\text { B-biotype, Korea } \\
\text { B-biotype, Korea }\end{array}$ & Q-biotype, Korea & 94.73 & 50.0 \\
B-biotype, Korea & BW2, Bangladesh(North) & 84.85 & 91.46 \\
B-biotype, Korea & BW3, Bangladesh(East) & 85.51 & 53.66 \\
Q-biotype, Korea & BW1, Bangladesh(South) & 83.55 & 54.15 \\
Q-biotype, Korea & BW2, Bangladesh(North) & 84.34 & 90.24 \\
Q-biotype, Korea & BW3, Bangladesh(East) & 84.87 & 87.38 \\
BW1, Bangladesh(South) & BW2, Bangladesh(North) & 90.26 & 54.88 \\
BW1, Bangladesh(South) & BW3, Bangladesh(East) & 84.61 & 58.54 \\
BW2, Bangladesh(North) & BW3, Bangladesh(East) & 86.32 & 89.29 \\
\hline
\end{tabular}

\section{Sequence analysis}

The profile of PCR amplification of 16S rRNA gene with primer, LR-J-12887 (5'- CCGGTTTGAACTCAGATCATGT-3'), LR-N-13398 (5'CGCCTGTTTAACAAAAACAT-3') showed consistent and single fragment of DNA in the length of $520 \mathrm{bp}$. Similarly, the primer set of C1-J-2195(F) and L2- 
N-3014(R) demonstrated consistent and single DNA fragment of 860 bp to distinguish the whiteflies including all biotypes (Figure 1). The sequences for all samples were obtained by purification of PCR product using ProMega Gel purified kit and can compare easily among the all sequences by clustalW2 alignment (Figure $2 \& 3$ ). Here, it was found dissimilarity score of BW3 are $15.39 \%$ and $13.68 \%$ for mtCOI gene and $41.46 \%$ and $10.71 \%$ for $16 \mathrm{~S}$ rRNA gene compared with BW1 and BW2, respectively (Table 3). Moreover, the sequences of mtCOI and 16S rRNA for BW3 were analyzed based on pairwise distance (character difference) and nucleotide different. It revealed that BW3 was highly divergent from B \& Q biotype (Korea), BW1 and BW2, which expressed 110 and 198 nucleotides were different from B biotype, 115 and 51 nucleotides were different from Q biotype, 117 and 204 nucleotides were different from BW1, 103 and 43 nucleotides were different from BW2 in mtCOI and 16S rRNA gene sequences, respectively (Table $4 \& 5$ ). These sequences of BW3 had shown the proportions of $\mathrm{A}+\mathrm{T}$ and $\mathrm{G}+\mathrm{C}$ in residue compositions of $69.0 \%$ and $31.0 \%$ for $\mathrm{mtCOI}$ as well as $73.7 \%$ and $26.3 \%$ for $16 \mathrm{~S}$ rRNA, respectively. The average proportion of T: C: A: G was 42.9: 13.0: 26.1: 18.0 for mtCOI and 30.4: 12.7: 43.3: 13.6 for 16S rRNA, respectively with a narrow standard error around means, but base composition varied substantially in different portions within the sequences of Bangladesh indigenous whiteflies. Among these $760 \mathrm{bp}$ nucleotide, 568 characters were conserved and 192 characters were variable (Table $6 \& 7$ ). The sequence divergence in pairwise comparisons revealed that BW3 was very diverse group of whitefly in phylogenetic tree where number of nucleotide changed 33-210 from each other, and lowest distance value was 0.053 and highest was 0.532 among all tested population (Table $4 \& 5$ ).

Table 4. Pairwise distance among 5 different biotypes of $B$. tabaci in Bangladesh based on sequences of the fragment of mtCOI gene.

\begin{tabular}{l|l|l|l|l|l}
\hline & 1 & 2 & 3 & 4 & 5 \\
\hline$[1]$ & & 0.099 & 0.154 & 0.159 & 0.165 \\
{$[2]$} & 75 & & 0.136 & 0.152 & 0.157 \\
{$[3]$} & 117 & 103 & & 0.145 & 0.152 \\
{$[4]$} & 121 & 115 & 110 & & 0.053 \\
{$[5]$} & 125 & 119 & 115 & 40 &
\end{tabular}

Table 5. Pairwise distance among 5 different biotypes of $B$. tabaci in Bangladesh based on sequences of the fragment of 16S rRNA gene.

\begin{tabular}{ll|l|l|l|l}
\hline & 1 & 2 & 3 & 4 & 5 \\
\hline$[1]$ & & 0.532 & 0.516 & 0.084 & 0.527 \\
{$[2]$} & 210 & & 0.109 & 0.514 & 0.101 \\
{$[3]$} & 204 & 43 & & 0.501 & 0.129 \\
{$[4]$} & 33 & 203 & 198 & & 0.511 \\
{$[5]$} & 208 & 40 & 51 & 202 & \\
\hline
\end{tabular}


(Bemisia tabaci from Southern part of Bangladesh (1), Northern part of Bangladesh (2), Eastern part of Bangladesh (3), B biotype from Korea (4); and Q biotype from Korea (5)). Distance in-between mtCOI gene for 5 different biotypes of $B$. tabaci in Bangladesh (below diagonal: total nucleotide differences, above diagonal: mean character differences) using Kimura 2-parameter (Bemisia tabaci from Southern part of Bangladesh (1), Northern part of Bangladesh (2), Eastern part of Bangladesh (3), B biotype from Korea (4); and Q biotype from Korea (5)). Distance in-between $16 \mathrm{~S}$ rRNA gene for 5 different biotypes of $B$. tabaci in Bangladesh (below diagonal: total nucleotide differences, above diagonal: mean character differences) using Kimura 2-parameter

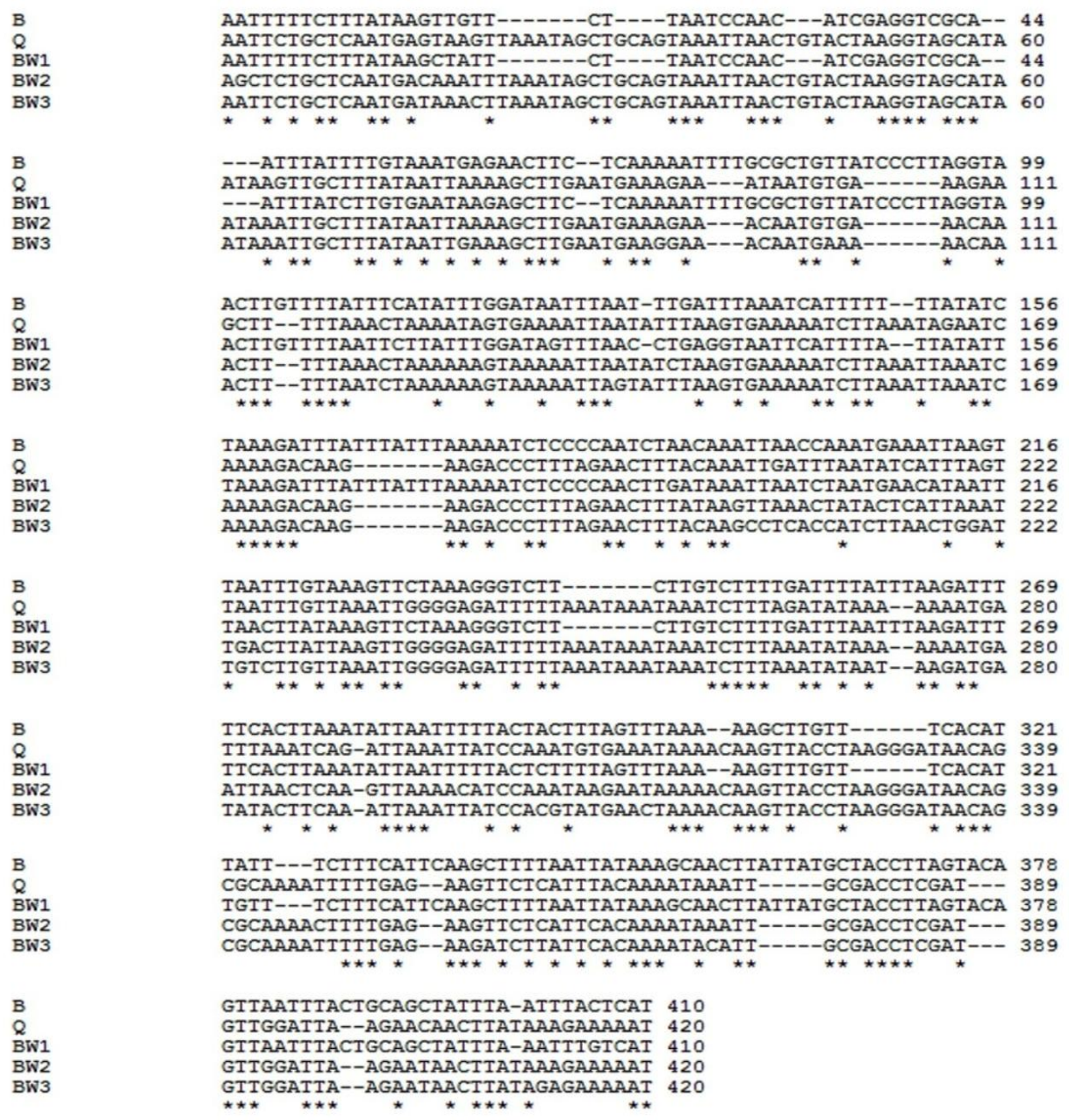

Fig. 2. Sequence alignment of Bangladesh whitefly (BW1, BW2 and BW3) and compared with $B$ and $Q$ biotype of Korea using 16S rRNA gene nucleotide sequences by ClustalW2 program. 


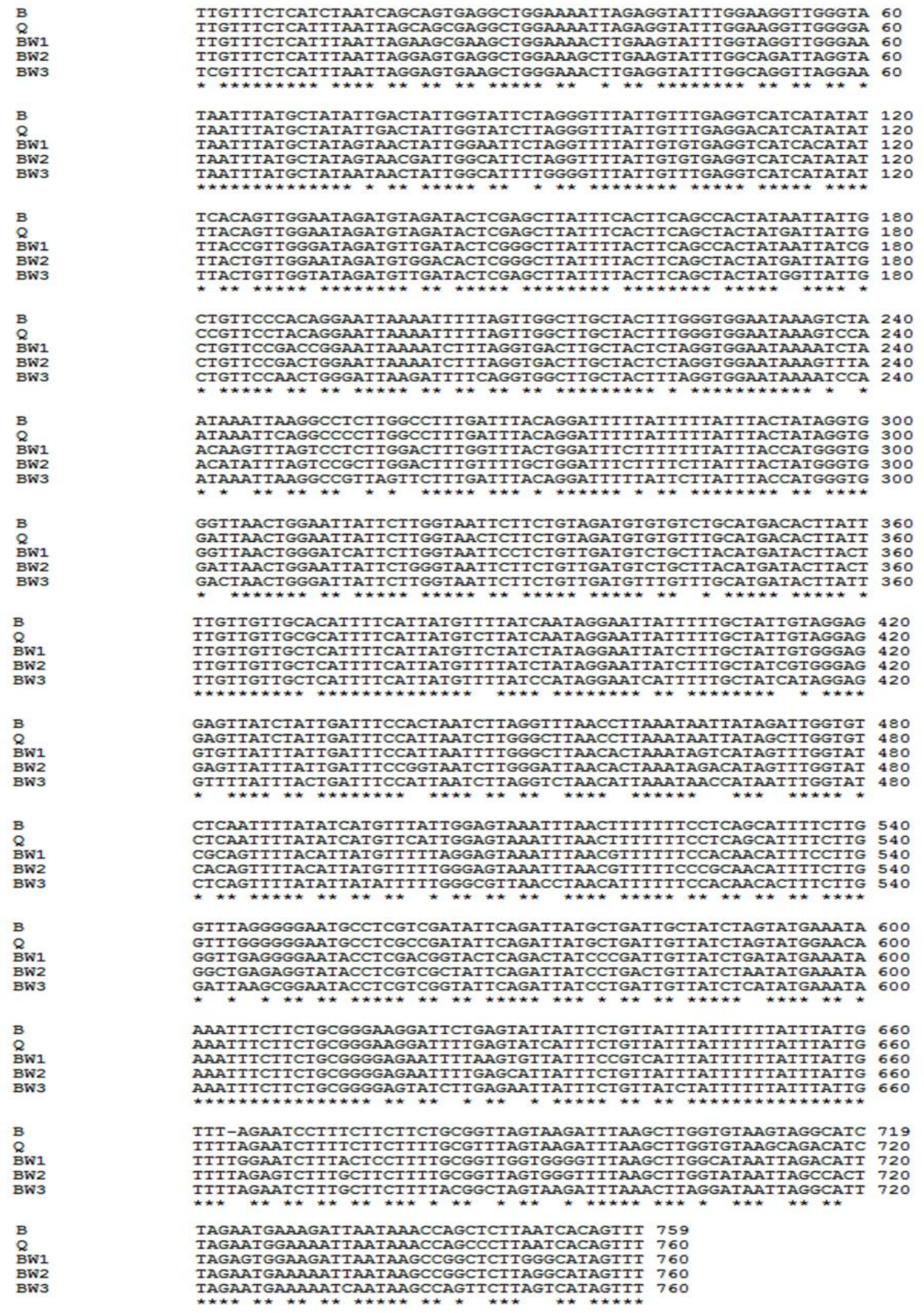

Fig. 3. Sequence alignment of Bangladesh whitefly (BW1, BW2 and BW3) and compared with $B$ and $Q$ biotype of Korea using mtCOI region nucleotide sequences by ClustalW2 program 


\section{Phylogenetic analysis}

The Neibour-joining phylogenetic tree reconstruction based on 21 mitochondrial cytochrome oxidase subunit-I (mtCOI) sequences (B biotype from Israel, Viet Nam, China and Korea; Q biotype from Costa Rica, China, Egypt and Korea; BW1 from southern part of Bangladesh, BW2 from northern part of Bangladesh and newly collected Indigenous $B$. tabaci from eastern part of Bangladesh were compared) is shown in Figure 6. It revealed that mtCOI sequence of B. tabaci of eastern part of Bangladesh from Chittagong and Cox's Bazar which collected from bean, eggplant and okra were clustered together individually with high distance from each other (Figure 4). It was clear that third genotypic cluster was present in Bangladesh indigenous whiteflies which was BW3. Here mtCOI sequence of Aleurodicus dispersus was used as out group of phylogeny.

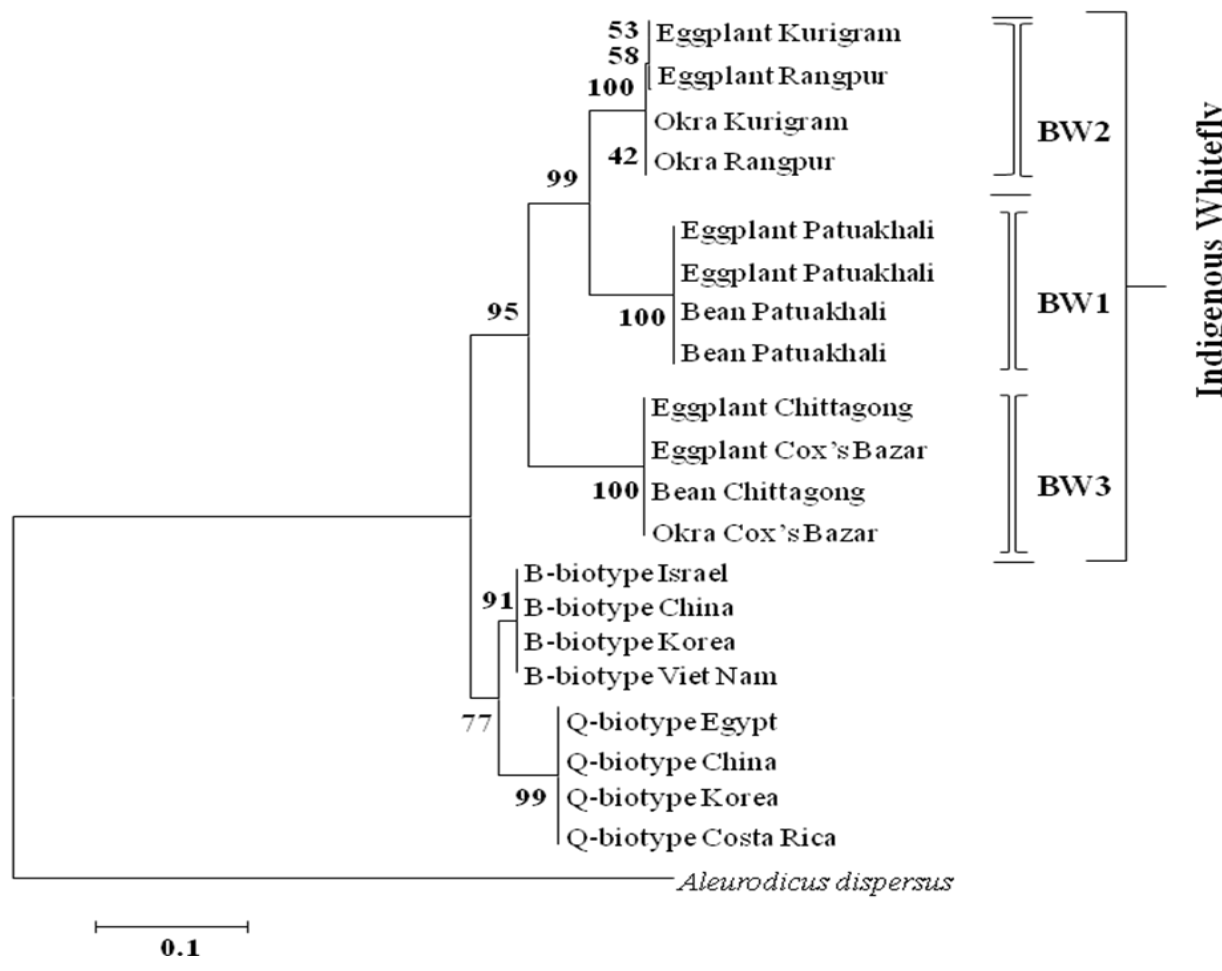

Fig. 4. Phylogenetic relationships of $B$. tabaci populations based on a fragment $(\sim 860 \mathrm{bp})$ of the mitochondrial COI sequences. Neibour-joining phylogenetic tree reconstructed using the whitefly mitochondrial cytochrome oxidase subunit-I (mtCOI) sequences as a molecular marker according to the Bayesian method. The numbers placed at each node indicate the bootstrap support for values $>\mathbf{5 0}$. The horizontal branch length is drawn to scale, and the bar indicates the distance of $0.1 \mathrm{nt}$ replacements per site. 
THE THIRD GENOTYPIC CLUSTERS

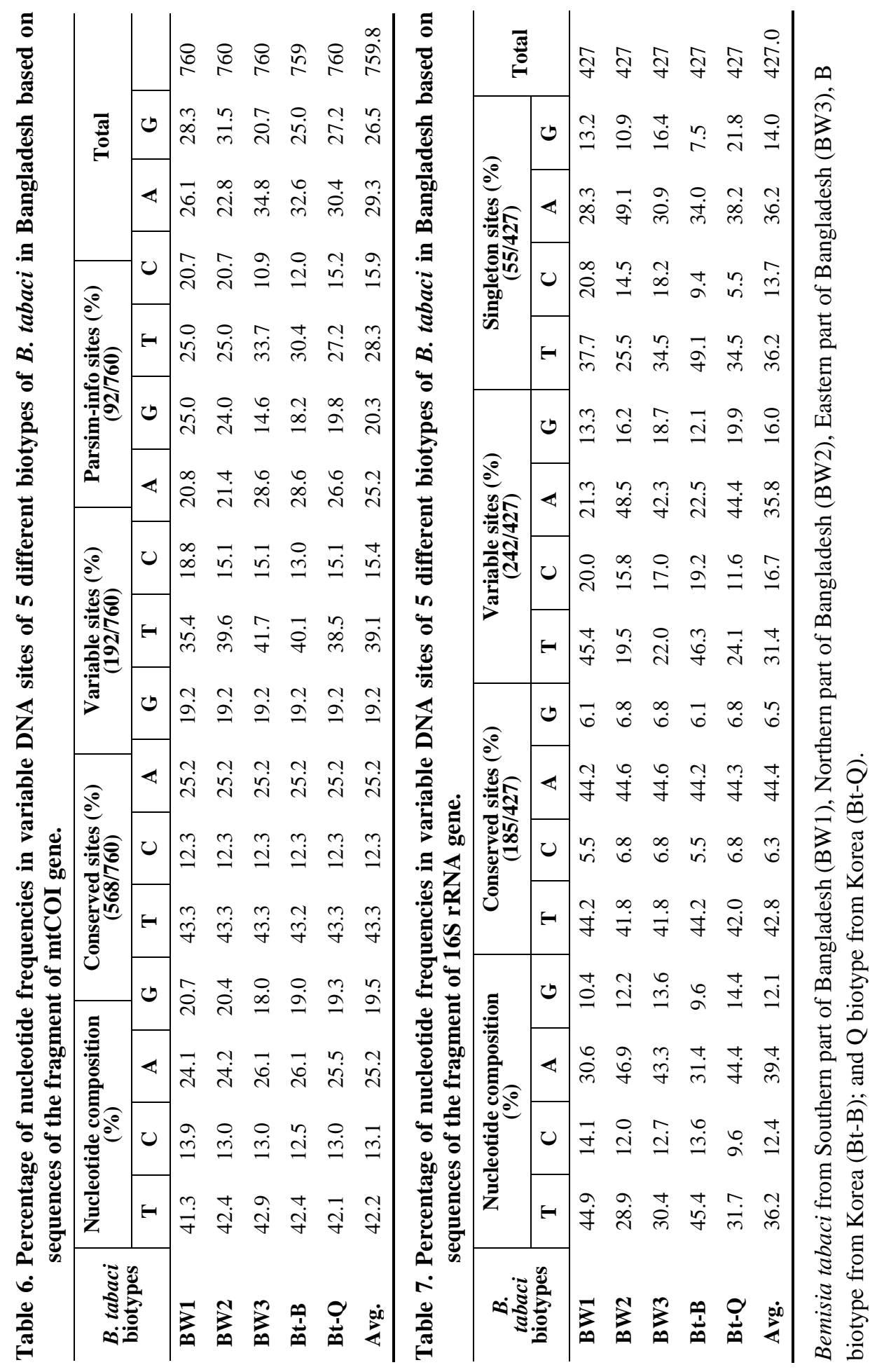


The same analysis constructed by Neibour-joining phylogenetic tree based on twenty three 16S ribosomal RNA (16S rRNA) sequences (B biotype from Israel, China and Korea; Q biotype from Spain, China and Korea; Indigenous B. tabaci BW1 and BW2 from southern part and northern part of Bangladesh, China, India, Pakistan, Sri Lanka and Japan were compared with newly collected whitefly from eastern part of Bangladesh) is shown in Figure 5. It revealed that ribosomal RNA (16S rRNA) sequences of B. tabaci of eastern part of Bangladesh which was collected from bean, eggplant and okra were clustered together individually with high distance from each other (Figure 5). It is undoubtedly revealed that third genotypic cluster of B. tabaci in Bangladesh which is BW3.

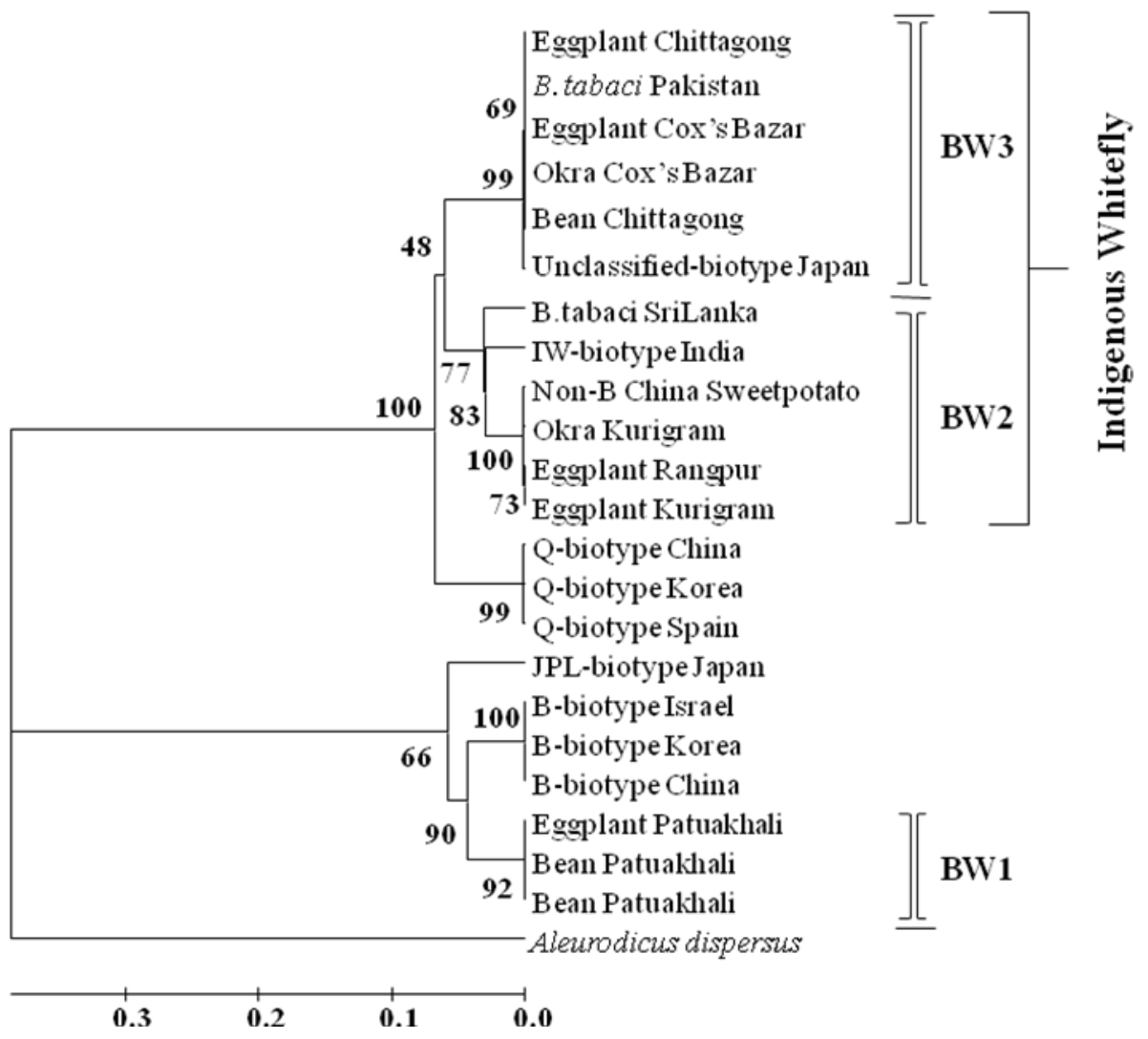

Fig. 5. Phylogenetic relationships of $B$. tabaci populations based on a fragment $(\sim 520 \mathrm{bp})$ of the mitochondrial $16 \mathrm{~S}$ rRNA sequences. Neibour-joining phylogenetic tree reconstructed using the whitefly $16 S$ ribosomal RNA (16S rRNA) sequences as a molecular marker according to the Bayesian method. The numbers placed at each node indicate the bootstrap support for values $>$ 50. The horizontal branch length is drawn to scale, and the bar indicates $0.0-0.3 \mathrm{nt}$ replacements per site. 


\section{Discussion}

Bemisia tabaci populations revealed high genetic diversity in southern Asia. Phylogenetic analysis of mtCOI and 16S rRNA gene sequence data can be separated clearly the B. tabaci samples into north, south and east indigenous groups of Bangladeshi whitefly (Figure $4 \& 5$ ). Different cropping pattern and diverse climatic conditions in the northern, eastern and southern regions of Bangladesh may be responsible for the apparent diversity in $B$. tabaci, which otherwise grouped in geographic location. Tobacco, potato, and vegetables are grown almost as monocultures in the dry arid conditions in Kurigram, northern part of Bangladesh whereas the south is relatively cool and mixed crops of cereals, pulses, and vegetables predominate. However, divisions were not based on the host-plant from which the samples were collected, which was one of the criteria used to identify two B. tabaci biotypes (cassava and sweet potato) in south India (Lisha et al., 2003). The RAPD-PCR technique has been used before to distinguish indigenous populations of $B$. tabaci from those of the introduced B biotype (Gawel \& Bartlett, 1993; Perring et al., 1993; De Barro \& Driver, 1997; Guirao et al., 1997; Moya et al., 2001). Based on phylogenetic analyses of mtCOI and 16S rRNA gene sequences, the Asian B. tabaci formed three clusters each supported with a high bootstrap score, which indicate the existence of at least two genotypic clusters (BW1 and BW2) of $B$. tabaci indigenous to Bangladesh. This may support the conclusion of De Barro et al. (2005) that using $\mathrm{mtCOI}$ and internal transcribed spacer region 1 (ITS1) markers, some individuals from Asia did not fit into either of the two clusters (called Asia1 and Asia2), and they remained classified as 'unresolved' in the Asia group.

This research work has been successfully carried out for monitoring $B$. tabaci and detecting its genotypic clusters from Bangladesh. Jahan et al. (2011) previously mentioned that all Bangladeshi whiteflies were indigenous and there was apparently absent $\mathrm{B}$ and $\mathrm{Q}$ biotype of $\mathrm{B}$. tabaci. The present findings also supported the previous report of Jahan et al., 2011. In the present study for detecting the third genotypic cluster of $B$. tabaci, it was found that whiteflies of eastern part of Bangladesh make a distinct clade in Phylogenetic tree based on mtCOI and 16S rRNA sequences separately (Figure $4 \& 5$ ). Although, Jahan (2012) reported two genotypic clusters present in Bangladesh. However, all sequences data currently found in GenBank were compared for preparing the phylogeny of whiteflies using mtCOI sequences of different biotypes including indigenous whiteflies from different countries.

Some Bangladeshi B. tabaci shared about $99 \%$ mtCOI sequence identity with populations from other Asian countries like India, Pakistan, Myanmar, Japan and Nepal. There may be several explanations for this, including the existence of a cline of distinct $B$. tabaci genotypes across Asian countries that allow gene flow between them. Huge geographical distances and natural barriers, such as the Himalayan mountain range, however, represent significant physical barriers for 
natural movement and therefore probably restrict gene flow, for example, between the Bangladesh and Myanmar B. tabaci populations. The most likely reason for the similarity of these populations may be the movement of $B$. tabaci between the countries as a result of human activities. The most recent example of such introduction has been the arrival of the B biotype in India, Pakistan, and China (Banks et al., 2001; Simon et al., 2003; Zhang et al., 2005), and more recently the Q biotype in China (Zhang et al., 2005). The data, which presented here, highlight the real and increasing threat posed by the movement of $B$. tabaci and potentially new viruses to agriculture in Asia.

Phylogenetic analysis of mtCOI and 16S rRNA gene sequences with reference $B$. tabaci sequences from other countries divided them into two genotypic clusters. Each cluster supported with high bootstrap values (55-100\%) and the individuals belonging to each cluster shared high nucleotide identities (up to 100\%) (Figure 6 \& 7). This result supported by Rekha et al. (2005) who reported that at least three distinct genotypes, of indigenous whitefly to India, which are also present in China, Malaysia, Nepal, Pakistan, Japan and Thailand.

\section{References}

Ahmed, M.Z., R.G. Shatters, S.X. Ren, G.H. Jin, N.S. Mandour, B.L. Qiu, 2009. Genetic distinctions among the Mediterranean and Chinese populations of Bemisia tabaci $\mathrm{Q}$ biotype and their Wolbachia infection. J. Appl. Entomol. 133: 733-741

Banks, G. K., J. Colvin, R. R. V. Chowda, M. N. Maruthi, V. Muniyappa, H. M. Venkatesh, K. M. Kiran, A. S. Padmaja, F. J. Beitia, S. E. Seal, 2001. First report of the Bemisia tabaci B biotype in India and an associated tomato leaf curl virus disease epidemic. Plant Disease 85: 231.

Berry, S.D., V.N. Fondong, C. Rey, D. Rogan, C.M. Fauquet, J.K. Brown, 2004. Molecular evidence for five distinct Bemisia tabaci (Homoptera: Aleyrodidae) geographic haplotypes associated with cassava plants in Sub-Saharan Africa. Ann. Entomol. Soc. Am. 97: 852-859.

Boykin, L.M., R.G. Shatters, R.C. Rosell, C.L. McKenzie, R. Bagnall, P. De Barro, D.R. Frohlich, 2007. Global relationships of Bemisia tabaci (Hemiptera: Aleyrodidae) revealed using Bayesian analysis of mitochondrial COI DNA sequences. Mol. Phylogenet. Evol. 44: 1306-1319.

Brown, J. K. 2001. Molecular markers for the identification and global tracking of whitefly vector-begomovirus complexes. Virus Research, 71: 233-260.

Chu, D., Y.J. Zhang, J.K. Brown, B. Cong, B.Y. Xu, Q.J. Wu, G.R. Zhu, 2006. The introduction of the exotic Q biotype of Bemisia tabaci from the Mediterranean region into China on ornamental crops. Fla. Entomol. 89:168-174.

De Barro, P. J., F. Driver, 1997. Use of RAPD PCR to distinguish the B biotype from other biotypes of Bemisia tabaci (Gennadius) (Hemiptera: Aleyrodidae). Australian Journal of Entomology 36: 149-152. 
De Barro, P. J., J. W. H. Trueman, D. R. Frohlich, 2005. Bemisia argentifolii is a race of B. tabaci (Hemiptera: Aleyrodidae): the molecular genetic differentiation of $B$. tabaci populations around the world. Bulletin of Entomological Research 95: 1-11.

De Barro, P.J. 2005. Genetic structure of the whitefly Bemisia tabaci in the Asia-Pacific region revealed using microsatellite markers. Mol. Ecol. 14:3695-3718.

De Barro, P.J., F. Driver, J.W.H. Trueman, J. Curran, 2000. Phylogenetic relationships of world populations of Bemisia tabaci (Gennadius) using ribosomal ITS1. Mol. Phylogenet. Evol. 16: 29-36.

Dellaporta, S., J. Wood, J.B. Hicks, 1983. A plant DNA minipreparation: version II. Plant. Mol. Biol. Rept. 1:19-21.

Frohlich, D.R., I. Torres-Jerez, I.D. Bedford, P.G. Markham, J.K. Brown, 1999. A phylogeographical analysis of the Bemisia tabaci species complex based on mitochondrial DNA markers. Mol. Ecol. 8:1683-1691.

Gawel, N. J., A. C. Bartlett, 1993. Characterisation of differences between whiteflies using RAPD-PCR. Insect Molecular Biology 2: 33-38.

Guirao, P., F. Beitia, J.L. Cenis, 1997. Biotype determination of Spanish populations of Bemisia tabaci (Hemiptera: Aleyrodidae). Bull. Entomol. Res. 87: 587-593.

Jahan, S. M. H. 2012. Occurrence of two genotypic clusters of Bemisia tabaci (Gennadius) (Hemiptera: Aleyrodidae) in Bangladesh. Eco-friendly Agril. J. 5(08): 114-122.

Jahan, S.M.H., M.A. Rahman, M. Asaduzzaman, K-Y. Lee, 2011. Molecular identification of sweetpotato whitefly Bemisia tabaci (Gennadius)(Homoptera: Aleyrodidae) and biotype detection in Bangladesh. Bangladesh Journal of Environmental Science. 20: 73-78.

Jones, D.R. 2003. Plant viruses transmitted by whiteflies. Eur. J. Plant Pathol. 109:195219.

Legg, J. P., R. French, D. Rogan, G. Okao-Okuja, J. K. Brown, 2002. A distinct Bemisia tabaci (Gennadius) (Hemiptera: Sternorrhyncha: Aleyrodidae) genotype cluster is associated with the epidemic of severe cassava mosaic virus disease in Uganda. Molecular Ecology 11: 1219-1229.

Lisha, V. S., B. Antony, M. S. Palaniswami, T. J. Henneberry, 2003. Bemisia tabaci (Genn.) biotypes in India. Journal of Economic Entomology. 96: 322-327.

Martin, J.H., D. Mifsud, , C. Rapisarda, 2000. The whiteflies (Hemiptera : Aleyrodidae) of Europe and the Mediterranean Basin. Bull. Entomol. Res. 90: 407-448.

Martinez-Carrillo, J.L., J.K. Brown, 2007. First report of the Q biotype of Bemisia tabaci in southern Sonora, Mexico. Phytoparasitica. 35: 282-284.

Maruthi, M. N., A. R. Rekha, S. H. Mirza, S. N. Alam, J. Colvin, 2007. PCR-based detection and partial genome sequencing indicate high genetic diversity in Bangladeshi begomoviruses and their whitefly vector, Bemisia tabaci. Virus Genes. 34: 373-385.

Moya, A., P. Guirao, D. Cifuentes, F. Beitia, J.L. Cenis, 2001. Genetic diversity of Iberian populations of Bemisia tabaci (Hemiptera: Aleyrodidae) based on random amplified polymorphic DNA-polymerase chain reaction. Mol. Ecol. 10: 891-897. 
Mughra, R.B., S.S. Liu, X. Zhou, 2008. Tomato yellow leaf curl virus and tomato leaf curl taiwan virus invade south-east coast of China. J. Phytopathol. 156: 217-221.

Perring, T. M., A. D. Cooper, R. J. Rodriguez, C. A. Farrar, T. S. Bellows, 1993. Identification of a whitefly species by genomic and behavioural studies. Science 259: 74-77.

Perring, T.M. 2001. The Bemisia tabaci species complex. Crop Protection, 20: 725-737.

Rekha, A.R., M. N. Maruthi, V. Muniyappa, J. Colvin, 2005. Occurrence of three genotypic clusters of Bemisia tabaci and the rapid spread of the B biotype in south India Entomologia Experimentalis et Applicata, $117: 221-233$.

Simon, B., J.L. Cenis, S. Demichelis, C. Rapisarda P. Caciagli, D. Bosco, 2003. Survey of Bemisia tabaci (Hemiptera: Aleyrodidae) biotypes in Italy with the description of a new biotype T from Euphorbia characias. Bull. Entomol. Res. 93: 259-264.

Simon, C., F. Frati, A. Beckenbach, B. Crespi, H. Liu, P. Flook, 1994. Evolution, weighting, and phylogenetic utility of mitochondrial gene sequences and a compilation of conserved polymerase chain reaction primers. Ann. Entomol. Soc. Am. 87: 651-701

Tamura, K., J. Dudley, M. Nei, S. Kumar, 2007. MEGA4: Molecular Evolutionary Genetics Analysis (MEGA) software version 4.0. Molecular Biology and Evolution 24: 1596-1599.

Thompson, J. D., D. G. Higgins, T. J. Gibson, 1994. CLUSTAL W: improving the sensitivity of progressive multiple sequence alignment through sequence weighting, positions-specific gap penalties and weight matrix choice. Nuc. Ac. Res. 22: 46734680 .

Zhang, L. P., Y. J. Zhang, W. J. Zhang, Q. J. Wu, B. Y. Xu, D. Chu, 2005. Analysis of genetic diversity among different geographical populations and determination of biotypes of Bemisia tabaci in China. Journal of Applied Entomology 129: 121-128. 